Cellular Physiology
and Biochemistry and Biochemistry Published online: March 11, 2016

Accepted: February 17, 2016

This article is licensed under the Creative Commons Attribution-NonCommercial-NoDerivatives 4.0 International License (CC BY-NC-ND) (http://www.karger.com/Services/OpenAccessLicense). Usage and distribution for commercial purposes as well as any distribution of modified material requires written permission.

\title{
Stimulating Effect of Manumycin A on Suicidal Erythrocyte Death
}

\author{
Jasmin Egler ${ }^{a, b} \quad$ Jens Zierle $e^{a, b} \quad$ Florian Lang ${ }^{a, b}$ \\ Departments of a Cardiology \& Vascular Medicine, and 'Physiology, University of Tübingen, Tuebingen, \\ Germany
}

\section{Key Words}

Phosphatidylserine - Cell volume - Eryptosis - SB203580 - Staurosporine - Calcium • Manumycin A

\begin{abstract}
Background/Aims: The streptomycete derived farnesyltransferase inhibitor Manumycin A triggers apoptosis of tumor cells and is thus considered for the treatment of malignancy. The present study explored whether Manumycin A could similarly stimulate eryptosis, the suicidal death of erythrocytes characterized by cell shrinkage and cell membrane scrambling with phosphatidylserine translocation to the erythrocyte surface. Stimulators of eryptosis include $\mathrm{Ca}^{2+}$ entry as well as activation of staurosporine sensitive protein kinase C and SB203580 sensitive p38 kinase. The present study explored, whether Manumycin A induces eryptosis and, if so, to shed some light on the mechanisms involved. Methods: Phosphatidylserine abundance at the human erythrocyte surface was estimated from annexin-V-binding, cell volume from forward scatter, and hemolysis from hemoglobin concentration in the supernatant. Results: A 48 hours exposure of human erythrocytes to Manumycin A ( $\geq 5 \mu \mathrm{g} / \mathrm{ml}$ ) significantly increased the percentage of annexin- $V$-binding cells, significantly decreased forward scatter and significantly incrased hemolysis. The effect of Manumycin $A$ on annexin-V-binding was significantly blunted by removal of extracellular $\mathrm{Ca}^{2+}$, by addition of staurosporine $(1 \mu \mathrm{M})$ and by addition of SB203580 $(2 \mu \mathrm{M})$. Conclusions: Manumycin A triggers hemolysis, cell shrinkage and phospholipid scrambling of the human erythrocyte cell membrane. The effect on cell membrane scrambling was in part but not fully dependent on entry of extracellular $\mathrm{Ca}^{2+}$, as well as activity of staurosporine and SB203580 sensitive kinases.
\end{abstract}

\section{Introduction}

The natural antibiotic [1-5] Manumycin A is a streptomycete derived farnesyltransferase inhibitor [6-15], Manumycin A downregulates the release of proinflammatory cytokines and thus counteracts inflammation [7] as well as atherosclerosis [3]. Moreover, manumycin A corrects aberrant splicing of the chloride channel Clcn 1 and may thus be effective in the 


\section{Cellular Physiology Cell Physiol Biochem 2016;38:1147-1156

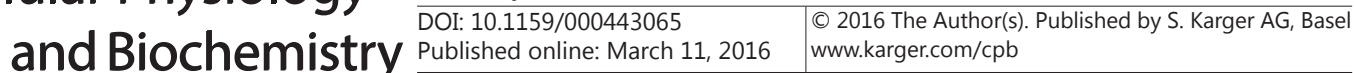 \\ Egler/Zierle/Lang: Manumycin A-Induced Eryptosis}

treatment of myotonic dystrophy type 1[16]. Manumycin A triggers suicidal death of tumor cells $[9,10,12,17-26]$ and the substance is effective against diverse malignancies $[6,8,17-22$, 27-35]. Mechanisms involved in Manumycin A induced apoptosis include inhibition of Ras $[5,6,8,11,13-15,26,27,29,33]$, HIF-1 $\alpha$ [8], and IkappaB kinase (IKK) [24, 32], activation of the mitochondrial apoptotic pathway $[17,21,23]$, oxidative stress $[18,20,22,30,31]$, as well as activation of caspases $[9,19,23]$.

Similar to apoptosis of nucleated cells, erythrocytes may enter eryptosis, the suicidal death of erythrocytes characterized by cell shrinkage [36] and cell membrane scrambling with phosphatidylserine translocation to the cell surface [37]. Triggers of eryptosis include $\mathrm{Ca}^{2+}$ entry with increase of cytosolic $\mathrm{Ca}^{2+}$ activity $\left(\left[\mathrm{Ca}^{2+}\right]_{\mathrm{i}}\right)[37]$, as well as activation of protein kinase C or of p38 kinase [37]. Eryptosis is elcited by a wide variety of xenobiotics [37-68].

The present study explored, whether exposure of human erythrocytes to Manumycin A stimulates eryptosis. To this end, erythrocytes isolated from healthy volunteers were treated with Manumycin A and cell volume, phosphatidylserine surface abundance, as well as hemolysis quantified.

\section{Materials and Methods}

\section{Erythrocytes, solutions and chemicals}

Fresh Li-Heparin-anticoagulated blood samples were kindly provided by the blood bank of the University of Tübingen. The study is approved by the ethics committee of the University of Tübingen (184/2003 V). The blood was centrifuged at $120 \mathrm{~g}$ for $20 \mathrm{~min}$ at $21^{\circ} \mathrm{C}$ and the platelets and leukocytes-containing supernatant was disposed. Erythrocytes were incubated in vitro at a hematocrit of $0.4 \%$ in Ringer solution containing (in $\mathrm{mM}$ ) $125 \mathrm{NaCl}, 5 \mathrm{KCl}, 1 \mathrm{MgSO}_{4}, 32 \mathrm{~N}$-2-hydroxyethylpiperazine-N-2-ethanesulfonic acid (HEPES; pH 7.4), 5 glucose, $1 \mathrm{CaCl}_{2}$, at $37^{\circ} \mathrm{C}$ for 48 hours. Where indicated, erythrocytes were exposed for 48 hours to Manumycin A (Enzo Life Sciences, Lörrach, Germany). To test for an involvement of p38 kinase, erythrocytes were exposed for 48 hours to a combination of Manumycin A and p38 kinase inhibitor SB 203580 (Tocris bioscience, Bristol, UK). To test for an involvement of protein kinase $\mathrm{C}$, erythrocytes were exposed for 48 hours to a combination of Manumycin A and staurosporine (Sigma Aldrich, Hamburg, Germany).

\section{Annexin-V-binding and forward scatter}

After incubation under the respective experimental condition, a $100 \mu$ l cell suspension was washed in Ringer solution containing $5 \mathrm{mM} \mathrm{CaCl}_{2}$ and then stained with Annexin-V-FITC (1:200 dilution; ImmunoTools, Friesoythe, Germany) in this solution at $37^{\circ} \mathrm{C}$ for 20 min under protection from light. The annexin-Vabundance at the erythrocyte surface was subsequently determined on a FACS Calibur (BD, Heidelberg, Germany). Annexin-V-binding was measured with an excitation wavelength of $488 \mathrm{~nm}$ and an emission wavelength of $530 \mathrm{~nm}$. A marker (M1) was placed to set an arbitrary threshold between annexin-V-binding cells and control cells. The same threshold was used for untreated and Manumycin A treated erythrocytes. A dot plot of forward scatter (FSC) vs. side scatter (SSC) was set to linear scale for both parameters. The threshold of forward scatter was set at the default value of " 52 ".

Intracellular $\mathrm{Ca}^{2+}$

After incubation, erythrocytes were washed in Ringer solution and loaded with Fluo-3/AM (Biotium, Hayward, USA) in Ringer solution containing $5 \mathrm{mM} \mathrm{CaCl}_{2}$ and $5 \mu \mathrm{M}$ Fluo-3/AM. The cells were incubated at $37^{\circ} \mathrm{C}$ for $30 \mathrm{~min} . \mathrm{Ca}^{2+}$-dependent fluorescence intensity was measured with an excitation wavelength of 488 $\mathrm{nm}$ and an emission wavelength of $530 \mathrm{~nm}$ on a FACS Calibur.

\section{Statistics}

Data are expressed as arithmetic means \pm SEM. As indicated in the figure legends, statistical analysis was made using ANOVA with Tukey's test as post-test and $t$ test as appropriate. $\mathrm{n}$ denotes the number of different erythrocyte specimens studied. Since different erythrocyte specimens used in distinct experiments are differently susceptible to triggers of eryptosis, the same erythrocyte specimens have been used for control and experimental conditions. 


\section{Results}

The present study explored whether Manumycin A stimulates eryptosis, the suicidal erythrocyte death characterized by cell shrinkage and by phospholipid scrambling of the cell membrane with phosphatidylserine translocation to the cell surface. To this end, the erythrocytes were incubated for 48 hours in Ringer solution without or with Manumycin A $(1-10 \mu \mathrm{g} / \mathrm{ml})$.

Erythrocyte volume was estimated from forward scatter which was determined utilizing flow cytometry. As illustrated in Fig. 1, Manumycin A decreased erythrocyte forward scatter, an effect reaching statistical significance at $5 \mu \mathrm{g} / \mathrm{ml}$ Manumycin A concentration. Along those lines treatment of erythrocytes with Manumycin A was followed by a significant increase of the percentage of shrunken erythrocytes (Fig. 1C), an effect reaching statistical significance at $5 \mu \mathrm{g} / \mathrm{ml}$ Manumycin A concentration. Manumycin A treatment simultaneously increased the percentage of swollen erythrocytes, an effect reaching statistical significance at $10 \mu \mathrm{g} /$ ml Manumycin A concentration (Fig. 1D).

The percentage of hemolytic erythrocytes was estimated from the hemoglobin concentration in the supernatant. As illustrated in Fig. 2, a 48 hours exposure to Manumycin A

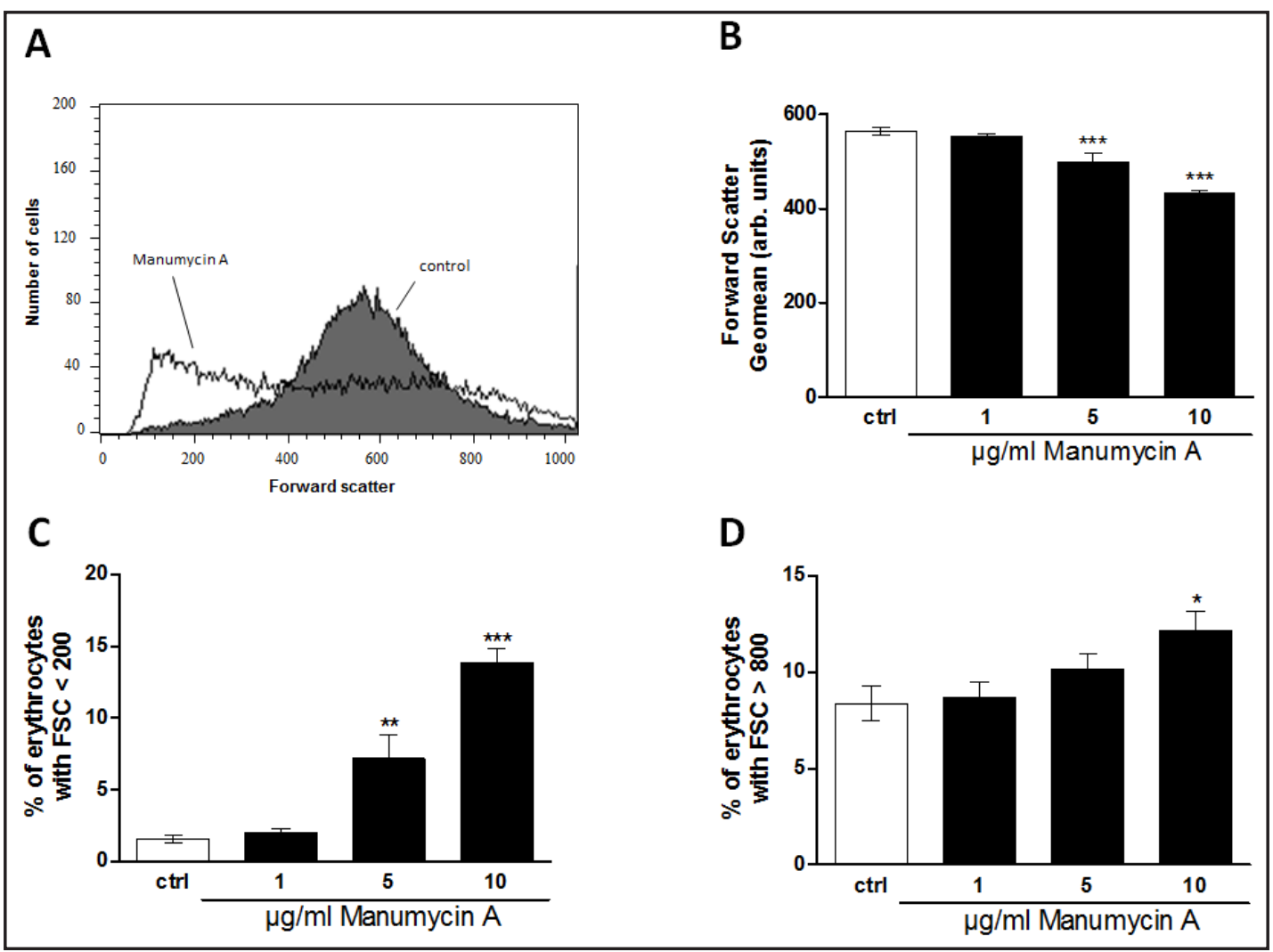

Fig. 1. Effect of Manumycin A on erythrocyte forward scatter. A. Original histogram of erythrocyte forward scatter following exposure for 48 hours to Ringer solution without (grey area) and with (black line) presence of $10 \mu \mathrm{g} / \mathrm{ml}$ Manumycin A. B. Arithmetic means \pm SEM $(\mathrm{n}=16)$ of the erythrocyte forward scatter (FSC) following incubation for 48 hours to Ringer solution without (white bar) or with (black bars) Manumycin A $(1-10 \mu \mathrm{g} / \mathrm{ml})$. C. Arithmetic means \pm SEM $(\mathrm{n}=16)$ of the percentage erythrocytes with forward scatter (FSC) <200 following incubation for 48 hours to Ringer solution without (white bar) or with (black bars) Manumycin A $(1-10 \mu \mathrm{g} / \mathrm{ml})$. D. Arithmetic means \pm SEM $(\mathrm{n}=16)$ of the percentage erythrocytes with forward scatter (FSC) $>800$ following incubation for 48 hours to Ringer solution without (white bar) or with (black bars) Manumycin A $(1-10 \mu \mathrm{g} / \mathrm{ml}) .{ }^{*}(\mathrm{p}<0.05),{ }^{* *}(\mathrm{p}<0.01),{ }^{* *}(\mathrm{p}<0.001)$ indicates significant difference from the absence of Manumycin A (ANOVA). 
Fig. 2. Effect of Manumycin A on hemolysis. Arithmetic means \pm SEM $(n=8)$ of the percentage hemolytic erythrocytes following incubation for 48 hours to Ringer solution without (white bar) or with (black bars) Manumycin A (1 - $10 \mu \mathrm{g} / \mathrm{ml}) .{ }^{* * *}(\mathrm{p}<0.001)$ indicates significant difference from the absence of Manumycin A (ANOVA).
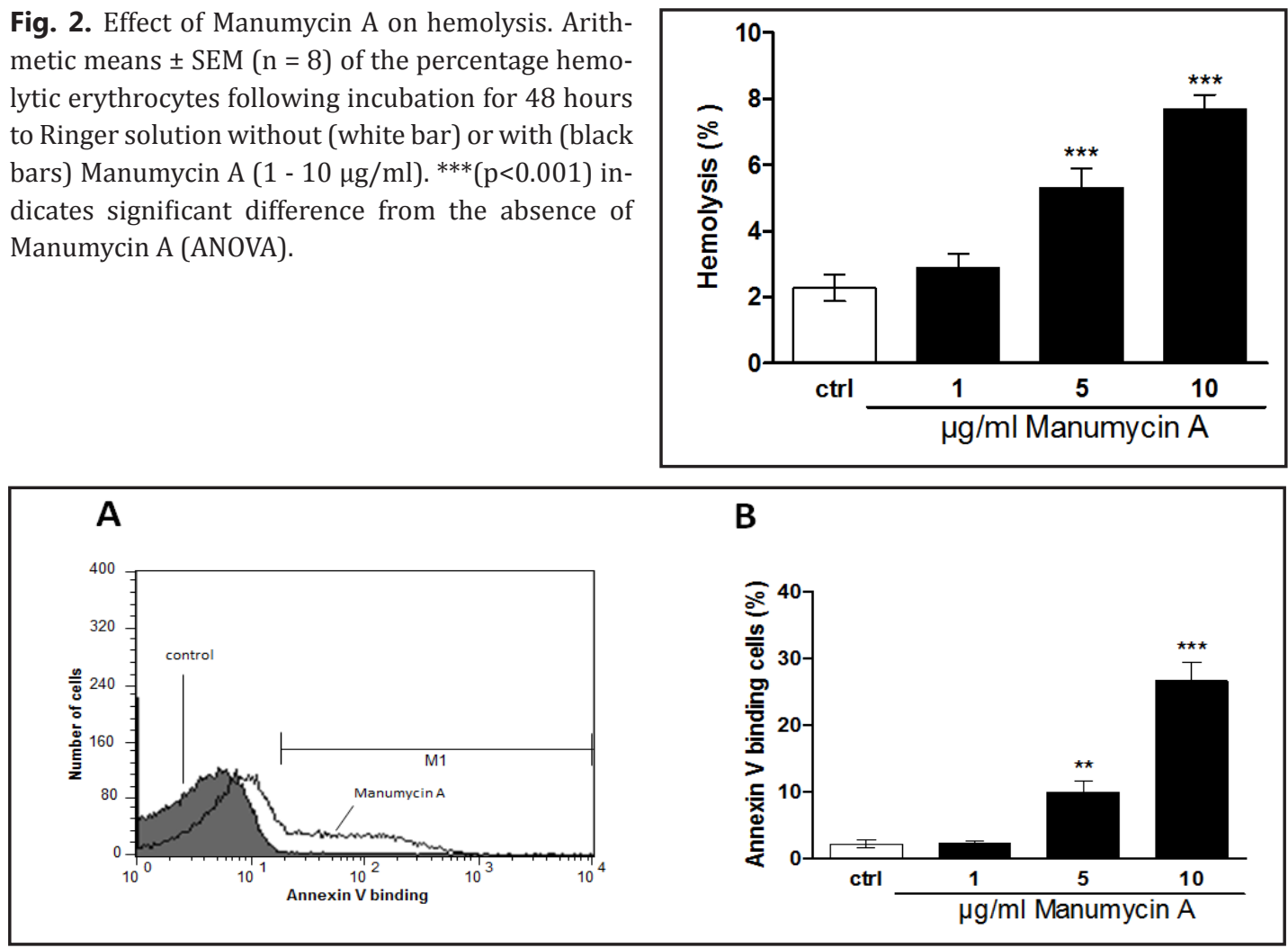

Fig. 3. Effect of Manumycin A on phosphatidylserine exposure. A. Original histogram of annexin-V-binding of erythrocytes following exposure for 48 hours to Ringer solution without (grey area) and with (black line) presence of $10 \mu \mathrm{g} / \mathrm{ml}$ Manumycin A. B. Arithmetic means \pm SEM $(\mathrm{n}=16)$ of the percentage annexinV-binding erythrocytes following incubation for 48 hours to Ringer solution without (white bar) or with (black bars) Manumycin A $(1-10 \mu \mathrm{g} / \mathrm{ml}) .{ }^{* *}(\mathrm{p}<0.01),{ }^{* * *}(\mathrm{p}<0.001)$ indicates significant difference from the absence of Manumycin A (ANOVA).

increased the percentage of hemolytic erythrocytes, an effect reaching statistical significance at $5 \mu \mathrm{g} / \mathrm{ml}$ Manumycin A.

Phosphatidylserine exposing erythrocytes were identified utilizing annexin-V-binding, as determined by flow cytometry. As illustrated in Fig. 3, a 48 hours exposure to Manumycin A increased the percentage of phosphatidylserine exposing erythrocytes, an effect reaching statistical significance at $5 \mu \mathrm{g} / \mathrm{ml}$ Manumycin A.

Fluo3 fluorescence was employed in an attempt to measure cytosolic $\mathrm{Ca}^{2+}$ activity $\left(\left[\mathrm{Ca}^{2+}\right]_{\mathrm{i}}\right)$. However, addition of Manumycin A increased the fluoresence even without staining of the erythrocytes with Fluo3. The interference precluded safe estimates of $\left[\mathrm{Ca}^{2+}\right]_{\mathrm{i}^{*}}$

In order to test whether Manumycin A-induced translocation of phosphatidylserine was sensitive to extracellular $\mathrm{Ca}^{2+}$, erythrocytes were incubated for 48 hours in the absence or presence of $10 \mu \mathrm{g} / \mathrm{ml}$ Manumycin A in the presence or nominal absence of extracellular $\mathrm{Ca}^{2+}$. As shown in Fig. 4, removal of extracellular $\mathrm{Ca}^{2+}$ significantly blunted the effect of Manumycin $A$ on the percentage of annexin-V-binding erythrocytes. However, even in the absence of extracellular $\mathrm{Ca}^{2+}$, Manumycin A significantly increased the percentage of annexin-V-binding erythrocytes. Thus, Manumycin A-induced cell membrane scrambling was in part, but not fully dependent on entry of extracellular $\mathrm{Ca}^{2+}$.

To explore, whether the effects of Manumycin A involved protein kinase C and/or p38 kinase activity, the influence of Manumycin A on annexin-V-binding was tested in the absence or presence of protein kinase $C$ inhibitor staurosporine $(1 \mu \mathrm{M})$ or p38 kinase inhibitor SB $203580(2 \mu \mathrm{M})$. As illustrated in Fig. 5, both staurosporine and SB203580 significantly 


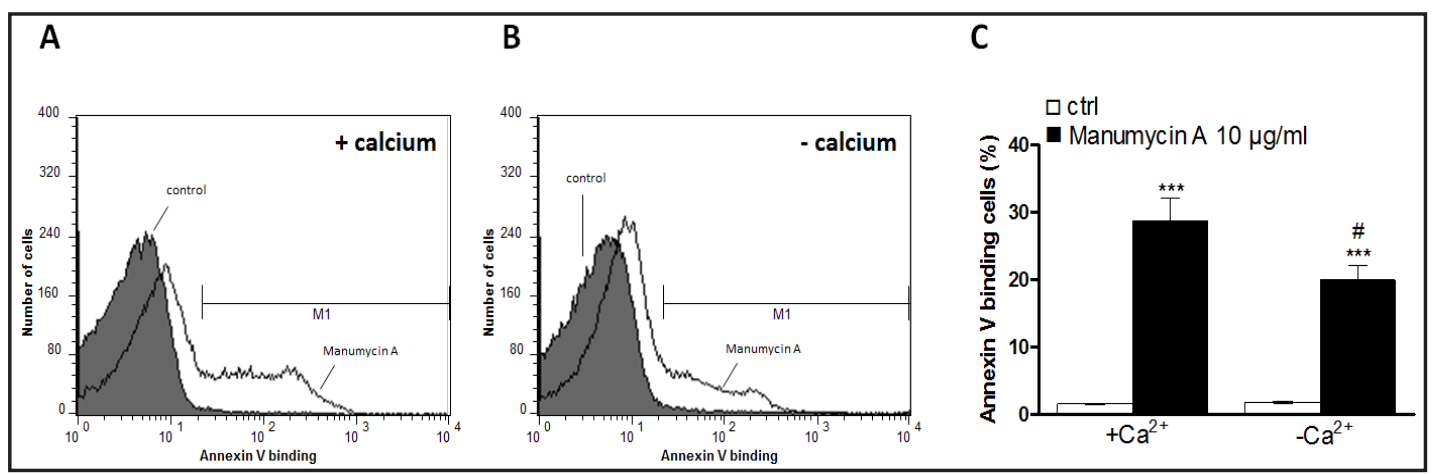

Fig. 4. $\mathrm{Ca}^{2+}$ sensitivity of Manumycin A -induced phosphatidylserine exposure. A,B. Original histogram of annexin-V-binding of erythrocytes following exposure for 48 hours to Ringer solution without (grey area) and with (black line) Manumycin A (10 $\mu \mathrm{g} / \mathrm{ml})$ in the presence (A) and absence (B) of extracellular $\mathrm{Ca}^{2+}$. C. Arithmetic means \pm SEM $(n=12)$ of annexin-V-binding of erythrocytes after a 48 hours treatment with Ringer solution without (white bars) or with (black bars) Manumycin A (10 $\mu \mathrm{g} / \mathrm{ml})$ in the presence (left bars, $\left.+\mathrm{Ca}^{2+}\right)$ and absence (right bars, $\left.-\mathrm{Ca}^{2+}\right)$ of $\mathrm{Ca}^{2+} .{ }^{* * *}(\mathrm{p}<0.001)$ indicates significant difference from the absence of Manumycin $\mathrm{A}, \#(\mathrm{p}<0.05)$ indicates significant difference from the presence of $\mathrm{Ca}^{2+}(\mathrm{ANOVA})$.

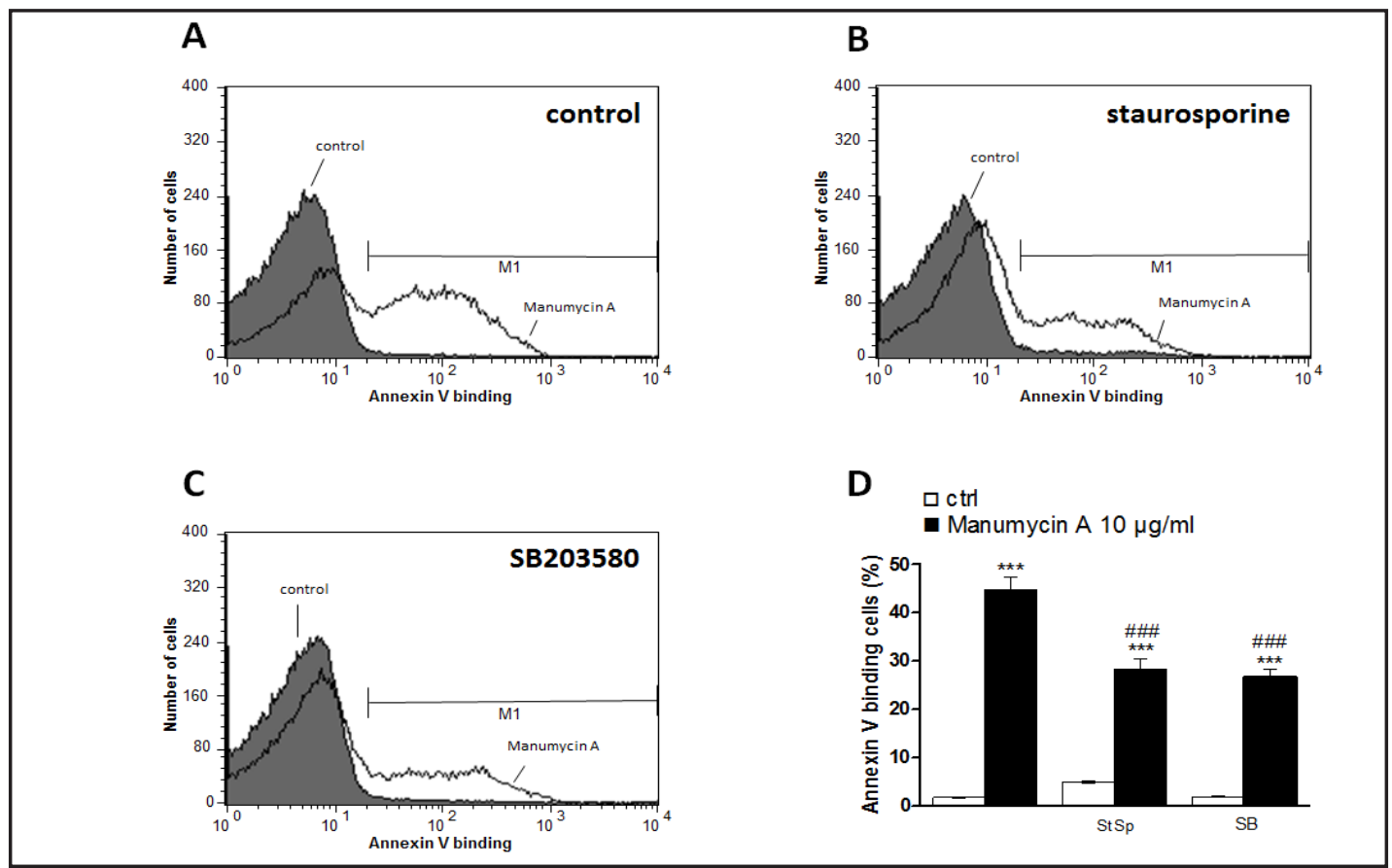

Fig. 5. Staurosporine and SB203580 sensitivity of Manumycin A -induced phosphatidylserine exposure. $\mathrm{A}, \mathrm{B}, \mathrm{C}$. Original histogram of annexin-V-binding of erythrocytes following exposure for 48 hours to Ringer solution without (grey area) and with (black line) Manumycin A $(10 \mu \mathrm{g} / \mathrm{ml})$ in the absence of kinase inhibitors (A) and in the presence of $1 \mu \mathrm{M}$ staurosporine (B) or of $2 \mu \mathrm{M} \mathrm{SB203580}$ (C). D. Arithmetic means \pm SEM ( $n=8)$ of annexin-V-binding of erythrocytes after a 48 hours treatment with Ringer solution without (white bars) or with (black bars) Manumycin A (10 $\mu \mathrm{g} / \mathrm{ml})$ in the absence of kinase inhibitors (left bars, control) and in the presence of $1 \mu \mathrm{M}$ staurosporine (middle bars, StSp) or of $2 \mu \mathrm{M}$ SB203580 (right bars, SB). *** $(\mathrm{p}<0.001)$ indicates significant difference from the absence of Manumycin $\mathrm{A}, \# \# \#(\mathrm{p}<0.001)$ indicates significant difference from the absence of kinase inhibitors (ANOVA).

blunted the effect of Manumycin A on the percentage of annexin-V-binding erythrocytes. However, even in the presence of the inhibitors, Manumycin A significantly increased the percentage of annexin-V-binding erythrocytes. Thus, Manumycin A-induced cell membrane scrambling was in part, but not fully dependent on kinase activity. 


\section{Discussion}

The present observations uncover a novel effect of Manumycin A, i.e. the triggering of eryptosis, the suicidal erythrocyte death. Exposure of erythrocytes from healthy individuals with Manumycin A was followed by cell shrinkage and cell membrane scrambling with phosphatidylserine translocation to the erythrocyte surface. The concentrations required for those effects were in the range of plasma concentrations determined in Manumycin A treated mice [69] and may thus be clinically relevant. Erythrocytes may be particularly sensitive to the proeryptotic effect of Manumycin A in clinical conditions with accelerated eryptosis, such as dehydration [70], hyperphosphatemia [71], chronic kidney disease (CKD) [72-75], hemolytic-uremic syndrome [76], diabetes [77], hepatic failure [78], malignancy [37], sepsis [79], sickle-cell disease [37], beta-thalassemia [37], Hb-C and G6PD-deficiency [37], as well as Wilsons disease [80].

Interference of Manumycin A with Fluo3 fluoresence measurements precluded safe estimates of cytosolic $\mathrm{Ca}^{2+}$ activity $\left(\left[\mathrm{Ca}^{2+}\right]_{\mathrm{i}}\right)$. However, the effect of Manumycin A on cell membrane scrambling was blunted by removal of $\mathrm{Ca}^{2+}$ from extracellular space, indicating that the effect was partially dependent on entry of extracellular $\mathrm{Ca}^{2+}$. The effect of Manumycin A on cell shrinkage may similarly be due to $\mathrm{Ca}^{2+}$ entry from the extracellular space leading to increase of $\left[\mathrm{Ca}^{2+}\right]_{\mathrm{i}}$ with subsequent activation of $\mathrm{Ca}^{2+}$ sensitive $\mathrm{K}^{+}$channels, $\mathrm{K}^{+}$exit, cell membrane hyperpolarization, $\mathrm{Cl}^{-}$exit and thus cellular loss of $\mathrm{KCl}$ with water [36]. It should be pointed out, however, that only a portion of treated erythrocytes underwent marked cell shrinkage. Another portion of erythrocytes even increased cell volume and some erythrocytes underwent hemolysis. The mechanism accounting for the cell swelling remained elusive. Feasible causes include ATP depletion with impairment of $\mathrm{Na}^{+} / \mathrm{K}^{+}$ATPase leading to cellular $\mathrm{Na}^{+}$accumulation, cellular loss of $\mathrm{K}^{+}$, depolarization and entry of $\mathrm{Cl}^{-}$.

As Manumycin A triggered cell membrane scrambling even in the absence of extracellular $\mathrm{Ca}^{2+}$, the drug was effective in part by mechanisms other than $\mathrm{Ca}^{2+}$ entry. Additional mechanisms apparently effective were activation of staurosporine and SB203580 sensitive kinases which have previously been shown to trigger eryptosis [37].

Eryptotic erythrocytes are rapidly cleared from circulating blood [37]. Thus eryptosis of defective erythrocytes may precede and thus prevent hemolysis with release of hemoglobin, which passes the renal glomerular filter, precipitates in the acidic lumen of renal tubules, occludes nephrons and thus may lead to renal failure [81]. Eryptosis is triggered by infection with the malaria pathogen Plasmodium and serves to remove infected erythrocytes from circulation [37].

The removal of phosphatidylserine exposing erythrocytes from circulating blood results in anemia as soon as the loss of erythrocytes exceeds the formation of new erythrocytes by erythropoiesis [37]. Phosphatidylserine exposing erythrocytes further adhere to the vascular wall [82], stimulate blood clotting and foster thrombosis [83-85]. Triggering of eryptosis may thus compromise microcirculation [83, 86-90].

In conclusion, Manumycin A triggers eryptosis with cell shrinkage and cell membrane scrambling, an effect in part dependent on $\mathrm{Ca}^{2+}$ entry and activation of staurosporine and SB203580 sensitive kinases.

\section{Acknowledgements}

The authors acknowledge the meticulous preparation of the manuscript by Tanja Loch. The study was supported by the Deutsche Forschungsgemeinschaft and the Open Access Publishing Fund of Tuebingen University.

\section{Disclosure Statement}

The authors of this manuscript state that they have no conflicts of interest to declare. 


\section{Cellular Physiology Cell Physiol Biochem 2016;38:1147-1156 \begin{tabular}{l|l|l} 
DOI: 10.1159/000443065 & (c) 2016 The Author(s). Published by S. Karger AG, Basel
\end{tabular} and Biochemistry Published online: March 11, $2016 \quad$ www.karger.com/cpb}

Egler/Zierle/Lang: Manumycin A-Induced Eryptosis

\section{References}

1 Li F, Jiang P, Zheng H, Wang S, Zhao G, Qin S, Liu Z: Draft genome sequence of the marine bacterium Streptomyces griseoaurantiacus M045, which produces novel manumycin-type antibiotics with a pABA core component. J Bacteriol 2011;193:3417-3418.

2 Xiong Q, Rikihisa Y: The prenylation inhibitor manumycin A reduces the viability of Anaplasma phagocytophilum. J Med Microbiol 2011;60:744-749.

3 Sugita M, Sugita H, Kaneki M: Farnesyltransferase inhibitor, manumycin a, prevents atherosclerosis development and reduces oxidative stress in apolipoprotein E-deficient mice. Arterioscler Thromb Vasc Biol 2007;27:1390-1395.

4 Ali BR, Pal A, Croft SL, Taylor RJ, Field MC: The farnesyltransferase inhibitor manumycin A is a novel trypanocide with a complex mode of action including major effects on mitochondria. Mol Biochem Parasitol 1999;104:67-80.

5 Kouchi H, Nakamura K, Fushimi K, Sakaguchi M, Miyazaki M, Ohe T, Namba M: Manumycin A, inhibitor of ras farnesyltransferase, inhibits proliferation and migration of rat vascular smooth muscle cells. Biochem Biophys Res Commun 1999;264:915-920.

6 Ito T, Kawata S, Tamura S, Igura T, Nagase T, Miyagawa JI, Yamazaki E, Ishiguro H, Matasuzawa Y: Suppression of human pancreatic cancer growth in BALB/c nude mice by manumycin, a farnesyl:protein transferase inhibitor. Jpn J Cancer Res 1996;87:113-116.

7 Cecrdlova E, Petrickova K, Kolesar L, Petricek M, Sekerkova A, Svachova V, Striz I: Manumycin A downregulates release of proinflammatory cytokines from TNF alpha stimulated human monocytes. Immunol Lett 2015;169:8-14.

8 Sharma V, Shaheen SS, Dixit D, Sen E: Farnesyltransferase inhibitor manumycin targets IL1beta-Ras-HIF1alpha axis in tumor cells of diverse origin. Inflammation 2012;35:516-519.

9 Frassanito MA, Mastromauro L, Cusmai A, Dammacco F: Blockade of the Ras pathway by manumycin, a farnesyltransferase inhibitor, overcomes the resistance of myeloma plasma cells to Fas-induced apoptosis. Clin Exp Med 2005;4:174-182.

10 Frassanito MA, Cusmai A, Piccoli C, Dammacco F: Manumycin inhibits farnesyltransferase and induces apoptosis of drug-resistant interleukin 6-producing myeloma cells. Br J Haematol 2002;118:157-165.

11 Hu W, Wu W, Yeung SC, Freedman RS, Kavanagh JJ, Verschraegen CF: Increased expression of heat shock protein 70 in adherent ovarian cancer and mesothelioma following treatment with manumycin, a farnesyl transferase inhibitor. Anticancer Res 2002;22:665-672.

12 Wang W, Macaulay RJ: Apoptosis of medulloblastoma cells in vitro follows inhibition of farnesylation using manumycin A. Int J Cancer 1999;82:430-434.

13 Kainuma O, Asano T, Hasegawa M, Kenmochi T, Nakagohri T, Tokoro Y, Isono K: Inhibition of growth and invasive activity of human pancreatic cancer cells by a farnesyltransferase inhibitor, manumycin. Pancreas 1997;15:379-383.

14 Nagase T, Kawata S, Tamura S, Matsuda Y, Inui Y, Yamasaki E, Ishiguro H, Ito T, Miyagawa J, Mitsui H, Yamamoto K, Kinoshita M, Matsuzawa Y: Manumycin and gliotoxin derivative KT7595 block Ras farnesylation and cell growth but do not disturb lamin farnesylation and localization in human tumour cells. Br J Cancer 1997;76:1001-1010.

15 Servais P, Gulbis B, Fokan D, Galand P: Effects of the farnesyltransferase inhibitor UCF-1C/manumycin on growth and p21-ras post-translational processing in NIH3T3 cells. Int J Cancer 1998;76:601-608.

16 Oana K, Oma Y, Suo S, Takahashi MP, Nishino I, Takeda S, Ishiura S: Manumycin A corrects aberrant splicing of Clcn1 in myotonic dystrophy type 1 (DM1) mice. Sci Rep 2013;3:2142.

17 Cho JJ, Chae JI, Kim KH, Cho JH, Jeon YJ, Oh HN, Yoon G, Yoon do Y, Cho YS, Cho SS, Shim JH: Manumycin A from a new Streptomyces strain induces endoplasmic reticulum stress-mediated cell death through specificity protein 1 signaling in human oral squamous cell carcinoma. Int J Oncol 2015;47:1954-1962.

18 Carey GB, Roy SK, Daino H: The natural tumorcide Manumycin-A targets protein phosphatase 1alpha and reduces hydrogen peroxide to induce lymphoma apoptosis. Exp Cell Res 2015;332:136-145.

19 Li JG, She MR, Lu CY, Wei SS, Xia PF, Lu ZS, Peng Q: Manumycin induces apoptosis in prostate cancer cells. Onco Targets Ther 2014;7:771-777.

20 She M, Yang H, Sun L, Yeung SC: Redox control of manumycin A-induced apoptosis in anaplastic thyroid cancer cells: involvement of the xenobiotic apoptotic pathway. Cancer Biol Ther 2006;5:275-280. 


\section{Cellular Physiology Cell Physiol Biochem 2016;38:1147-1156 \begin{tabular}{l|l|l}
\hline DOI: 10.1159/000443065 & $\begin{array}{l}\text { C) 2016 The Author(s). Published by S. Karger AG, Basel } \\
\text { www.karger.com/cpb }\end{array}$ \\
\hline
\end{tabular}

21 Pan J, Huang H, Sun L, Fang B, Yeung SC: Bcl-2-associated X protein is the main mediator of manumycin a-induced apoptosis in anaplastic thyroid cancer cells. J Clin Endocrinol Metab 2005;90:3583-3591.

22 She M, Pan I, Sun L, Yeung SC: Enhancement of manumycin A-induced apoptosis by methoxyamine in myeloid leukemia cells. Leukemia 2005;19:595-602.

23 Pan J, Xu G, Yeung SC: Cytochrome c release is upstream to activation of caspase-9, caspase-8, and caspase-3 in the enhanced apoptosis of anaplastic thyroid cancer cells induced by manumycin and paclitaxel. J Clin Endocrinol Metab 2001;86:4731-4740.

24 Zhou JM, Zhu XF, Pan QC, Liao DF, Li ZM, Liu ZC: Manumycin induces apoptosis in human hepatocellular carcinoma HepG2 cells. Int J Mol Med 2003;12:955-959.

25 Yang HL, Pan JX, Sun L, Yeung SC: p21 Waf-1 (Cip-1) enhances apoptosis induced by manumycin and paclitaxel in anaplastic thyroid cancer cells. J Clin Endocrinol Metab 2003;88:763-772.

26 Di Paolo A, Danesi R, Nardini D, Bocci G, Innocenti F, Fogli S, Barachini S, Marchetti A, Bevilacqua G, Del Tacca M: Manumycin inhibits ras signal transduction pathway and induces apoptosis in COLO320-DM human colon tumour cells. Br J Cancer 2000;82:905-912.

27 Sackova V, Kulikova L, Kello M, Uhrinova I, Fedorocko P: Enhanced antiproliferative and apoptotic response of HT-29 adenocarcinoma cells to combination of photoactivated hypericin and farnesyltransferase inhibitor manumycin A. Int J Mol Sci 2011;12:8388-8405.

28 Singha PK, Pandeswara S, Venkatachalam MA, Saikumar P: Manumycin A inhibits triple-negative breast cancer growth through LC3-mediated cytoplasmic vacuolation death. Cell Death Dis 2013;4:e457.

29 Tsuda M, Okamoto K, Muguruma N, Sannomiya K, Nakagawa T, Miyamoto H, Kitamura S, Goji T, Kimura T, Okahisa T, Izumi K, Takayama T: Suppressive effect of RAS inhibitor manumycin A on aberrant crypt foci formation in the azoxymethane-induced rat colorectal carcinogenesis model. J Gastroenterol Hepatol 2013;28:1616-1623.

30 Dixit D, Sharma V, Ghosh S, Koul N, Mishra PK, Sen E: Manumycin inhibits STAT3, telomerase activity, and growth of glioma cells by elevating intracellular reactive oxygen species generation. Free Radic Biol Med 2009;47:364-374.

31 Sears KT, Daino H, Carey GB: Reactive oxygen species-dependent destruction of MEK and Akt in Manumycin stimulated death of lymphoid tumor and myeloma cell lines. Int J Cancer 2008;122:1496-1505.

32 Bernier M, Kwon YK, Pandey SK, Zhu TN, Zhao RJ, Maciuk A, He HJ, Decabo R, Kole S: Binding of manumycin A inhibits IkappaB kinase beta activity. J Biol Chem 2006;281:2551-2561.

33 Zhou JM, Zhu XF, Pan QC, Liao DF, Li ZM, Liu ZC: Manumycin inhibits cell proliferation and the Ras signal transduction pathway in human hepatocellular carcinoma cells. Int J Mol Med 2003;11:767-771.

34 Xu G, Pan J, Martin C, Yeung SC: Angiogenesis inhibition in the in vivo antineoplastic effect of manumycin and paclitaxel against anaplastic thyroid carcinoma. J Clin Endocrinol Metab 2001;86:1769-1777.

35 Yeung SC, Xu G, Pan J, Christgen M, Bamiagis A: Manumycin enhances the cytotoxic effect of paclitaxel on anaplastic thyroid carcinoma cells. Cancer Res 2000;60:650-656.

36 Lang PA, Kaiser S, Myssina S, Wieder T, Lang F, Huber SM: Role of Ca2+-activated K+ channels in human erythrocyte apoptosis. Am J Physiol Cell Physiol 2003;285:C1553-C1560.

37 Lang E, Lang F: Mechanisms and pathophysiological significance of eryptosis, the suicidal erythrocyte death. Semin Cell Dev Biol 2015;39:35-42.

38 Alzoubi K, Calabròa S, Bissinger R, Abed M, Faggio C, Lang F: Stimulation of Suicidal Erythrocyte Death by Artesunate. Cell Physiol Biochem 2014;34:2232-2244.

39 Alzoubi K, Egler J, Abed M, Lang F: Enhanced Eryptosis Following Auranofin Exposure. Cell Physiol Biochem 2015;37:1018-1028.

40 Arnold M, Bissinger R, Lang F: Mitoxantrone-induced suicidal erythrocyte death. Cell Physiol Biochem 2014;34:1756-1767.

41 Arnold M, Lang E, Modicano P, Bissinger R, Faggio C, Abed M, Lang F: Effect of nitazoxanide on erythrocytes. Basic Clin Pharmacol Toxicol 2014;114:421-426.

42 Bissinger R, Barking S, Alzoubi K, Liu G, Liu G, Lang F: Stimulation of Suicidal Erythrocyte Death by the Antimalarial Drug Mefloquine. Cell Physiol Biochem 2015;36:1395-1405.

43 Bissinger R, Bouguerra G, Stockinger K, Abbes S, Lang F: Triggering of Suicidal Erythrocyte Death by Topotecan. Cell Physiol Biochem 2015;37:1607-1618.

44 Bissinger R, Fischer S, Jilani K, Lang F: Stimulation of Erythrocyte Death by Phloretin. Cell Physiol Biochem 2014;34:2256-2265. 


\section{Cellular Physiology Cell Physiol Biochem 2016;38:1147-1156 \begin{tabular}{l|l|l|l}
\hline DOI: 10.1159/000443065 & 2016 The Author(s). Published by S. Karger AG, Basel
\end{tabular} and Biochemistry Published online: March 11, $2016 \quad$ www.karger.com/cpb \\ Egler/Zierle/Lang: Manumycin A-Induced Eryptosis}

45 Bissinger R, Lupescu A, Zelenak C, Jilani K, Lang F: Stimulation of eryptosis by cryptotanshinone. Cell Physiol Biochem 2014;34:432-442.

46 Bouguerra G, Aljanadi O, Bissinger R, Abbes S, Lang F: Embelin-Induced Phosphatidylserine Translocation in the Erythrocyte Cell Membrane. Cell Physiol Biochem 2015;37:1629-1640.

47 Bouguerra G, Bissinger R, Abbes S, Lang F: Stimulation of Eryptosis by Narasin. Cell Physiol Biochem 2015;37:1807-1816.

48 Bouguerra G, Bissinger R, Abbes S, Lang F: Zopolrestat Induced Suicidal Death of Human Erythrocytes. Cell Physiol Biochem 2015;37:1537-1546.

49 Briglia M, Fazio A, Faggio C, Laufer S, Alzoubi K, Lang F: Triggering of Suicidal Erythrocyte Death by Ruxolitinib. Cell Physiol Biochem 2015;37:768-778.

50 Briglia M, Fazio A, Signoretto E, Faggio C, Lang F: Edelfosine Induced Suicidal Death of Human Erythrocytes. Cell Physiol Biochem 2015;37:2221-2230.

51 Calabro S, Alzoubi K, Faggio C, Laufer S, Lang F: Triggering of Suicidal Erythrocyte Death Following Boswellic Acid Exposure. Cell Physiol Biochem 2015;37:131-142.

52 Egler J, Lang F: Licochalcone A Induced Suicidal Death of Human Erythrocytes. Cell Physiol Biochem 2015;37:2060-2070.

53 Faggio C, Alzoubi K, Calabro S, Lang F: Stimulation of suicidal erythrocyte death by PRIMA-1. Cell Physiol Biochem 2015;35:529-540.

54 Fazio A, Briglia M, Faggio C, Alzoubi K, Lang F: Stimulation of Suicidal Erythrocyte Death by Garcinol. Cell Physiol Biochem 2015;37:805-815.

55 Jacobi J, Lang E, Bissinger R, Frauenfeld L, Modicano P, Faggio C, Abed M, Lang F: Stimulation of erythrocyte cell membrane scrambling by mitotane. Cell Physiol Biochem 2014;33:1516-1526.

56 Lang E, Jilani K, Bissinger R, Rexhepaj R, Zelenak C, Lupescu A, Lang F, Qadri SM: Vitamin D-Rich Diet in Mice Modulates Erythrocyte Survival. Kidney Blood Press Res 2015;40:403-412.

57 Lang E, Zelenak C, Eberhard M, Bissinger R, Rotte A, Ghashghaeinia M, Lupescu A, Lang F, Qadri SM: Impact of Cyclin-Dependent Kinase CDK4 Inhibition on Eryptosis. Cell Physiol Biochem 2015;37:1178-1186.

58 Lupescu A, Bissinger R, Goebel T, Salker MS, Alzoubi K, Liu G, Chirigiu L, Mack AF, Qadri SM, Lang F: Enhanced suicidal erythrocyte death contributing to anemia in the elderly. Cell Physiol Biochem 2015;36:773-783.

59 Lupescu A, Bissinger R, Herrmann T, Oswald G, Jilani K, Lang F: Induction of suicidal erythrocyte death by novobiocin. Cell Physiol Biochem 2014;33:670-680.

60 Lupescu A, Bissinger R, Warsi J, Jilani K, Lang F: Stimulation of erythrocyte cell membrane scrambling by gedunin. Cell Physiol Biochem 2014;33:1838-1848.

61 Malik A, Bissinger R, Calabro S, Faggio C, Jilani K, Lang F: Aristolochic Acid Induced Suicidal Erythrocyte Death. Kidney Blood Press Res 2014;39:408-419.

62 Officioso A, Alzoubi K, Manna C, Lang F: Clofazimine Induced Suicidal Death of Human Erythrocytes. Cell Physiol Biochem 2015;37:331-341.

63 Oswald G, Alzoubi K, Abed M, Lang F: Stimulation of suicidal erythrocyte death by ribavirin. Basic Clin Pharmacol Toxicol 2014;114:311-317.

64 Peter T, Bissinger R, Enkel S, Alzoubi K, Oswald G, Lang F: Programmed erythrocyte death following in vitro Treosulfan treatment. Cell Physiol Biochem 2015;35:1372-1380.

65 Stockinger K, Bissinger R, Bouguerra G, Abbes S, Lang F: Enhanced Eryptosis Following Exposure to Carnosic Acid. Cell Physiol Biochem 2015;37:1779-1791.

66 Tesoriere L, Attanzio A, Allegra M, Cilla A, Gentile C, Livrea MA: Oxysterol mixture in hypercholesterolemiarelevant proportion causes oxidative stress-dependent eryptosis. Cell Physiol Biochem 2014;34:1075-1089.

67 Waibel S, Bissinger R, Bouguerra G, Abbes S, Lang F: Saquinavir Induced Suicidal Death of Human Erythrocytes. Cell Physiol Biochem 2015;37:1973-1982.

68 Zierle J, Bissinger R, Egler J, Lang F: Lapatinib Induced Suicidal Death of Human Erythrocytes. Cell Physiol Biochem 2015;37:2275-2287.

69 Gonzales J, Jim Yeung SC, Smith JA: High-performance liquid chromatographic assay validation of Manumycin A in mouse plasma. J Chromatogr B Analyt Technol Biomed Life Sci 2002;776:177-182.

70 Abed M, Feger M, Alzoubi K, Pakladok T, Frauenfeld L, Geiger C, Towhid ST, Lang F: Sensitization of erythrocytes to suicidal erythrocyte death following water deprivation. Kidney Blood Press Res 2013;37:567-578. 


\section{Cellular Physiology Cell Physiol Biochem 2016;38:1147-1156 and Biochemistry \begin{tabular}{l|l} 
DOI: 10.1159/000443065 2016 & $\begin{array}{l}\text { C) 2016 The Author(s). Published by S. Karger AG, Basel } \\
\text { www.karger.com/cpb }\end{array}$
\end{tabular} \\ Egler/Zierle/Lang: Manumycin A-Induced Eryptosis}

71 Voelkl J, Alzoubi K, Mamar AK, Ahmed MS, Abed M, Lang F: Stimulation of suicidal erythrocyte death by increased extracellular phosphate concentrations. Kidney Blood Press Res 2013;38:42-51.

72 Abed M, Artunc F, Alzoubi K, Honisch S, Baumann D, Foller M, Lang F: Suicidal erythrocyte death in endstage renal disease. J Mol Med (Berl) 2014;92:871-879.

73 Ahmed MS, Langer H, Abed M, Voelkl J, Lang F: The uremic toxin acrolein promotes suicidal erythrocyte death. Kidney Blood Press Res 2013;37:158-167.

74 Polak-Jonkisz D, Purzyc L: Ca(2+) influx versus efflux during eryptosis in uremic erythrocytes. Blood Purif 2012;34:209-210; author reply 210.

75 Calderon-Salinas JV, Munoz-Reyes EG, Guerrero-Romero JF, Rodriguez-Moran M, Bracho-Riquelme RL, Carrera-Gracia MA, Quintanar-Escorza MA: Eryptosis and oxidative damage in type 2 diabetic mellitus patients with chronic kidney disease. Mol Cell Biochem 2011;357:171-179.

76 Lang PA, Beringer O, Nicolay JP, Amon O, Kempe DS, Hermle T, Attanasio P, Akel A, Schafer R, Friedrich B, Risler T, Baur M, Olbricht CJ, Zimmerhackl LB, Zipfel PF, Wieder T, Lang F: Suicidal death of erythrocytes in recurrent hemolytic uremic syndrome. J Mol Med (Berl) 2006;84:378-388.

77 Nicolay JP, Schneider J, Niemoeller OM, Artunc F, Portero-Otin M, Haik G, Jr., Thornalley PJ, Schleicher E, Wieder T, Lang F: Stimulation of suicidal erythrocyte death by methylglyoxal. Cell Physiol Biochem 2006;18:223-232.

78 Lang E, Gatidis S, Freise NF, Bock H, Kubitz R, Lauermann C, Orth HM, Klindt C, Schuier M, Keitel V, Reich M, Liu G, Schmidt S, Xu HC, Qadri SM, Herebian D, Pandyra AA, Mayatepek E, Gulbins E, Lang F, Haussinger D, Lang KS, Foller M, Lang PA: Conjugated bilirubin triggers anemia by inducing erythrocyte death. Hepatology 2015;61:275-284.

79 Kempe DS, Akel A, Lang PA, Hermle T, Biswas R, Muresanu J, Friedrich B, Dreischer P, Wolz C, Schumacher U, Peschel A, Gotz F, Doring G, Wieder T, Gulbins E, Lang F: Suicidal erythrocyte death in sepsis. J Mol Med (Berl) 2007;85:273-281.

80 Lang PA, Schenck M, Nicolay JP, Becker JU, Kempe DS, Lupescu A, Koka S, Eisele K, Klarl BA, Rubben H, Schmid KW, Mann K, Hildenbrand S, Hefter H, Huber SM, Wieder T, Erhardt A, Haussinger D, Gulbins E, Lang F: Liver cell death and anemia in Wilson disease involve acid sphingomyelinase and ceramide. Nat Med 2007;13:164-170.

81 Harrison HE, Bunting H, Ordway NK, Albrink WS: The Pathogenesis of the Renal Injury Produced in the Dog by Hemoglobin or Methemoglobin. J Exp Med 1947;86:339-356.

82 Borst O, Abed M, Alesutan I, Towhid ST, Qadri SM, Foller M, Gawaz M, Lang F: Dynamic adhesion of eryptotic erythrocytes to endothelial cells via CXCL16/SR-PSOX. Am J Physiol Cell Physiol 2012;302:C644-C651.

83 Andrews DA, Low PS: Role of red blood cells in thrombosis. Curr Opin Hematol 1999;6:76-82.

84 Chung SM, Bae ON, Lim KM, Noh JY, Lee MY, Jung YS, Chung JH: Lysophosphatidic acid induces thrombogenic activity through phosphatidylserine exposure and procoagulant microvesicle generation in human erythrocytes. Arterioscler Thromb Vasc Biol 2007;27:414-421.

85 Zwaal RF, Comfurius P, Bevers EM: Surface exposure of phosphatidylserine in pathological cells. Cell Mol Life Sci 2005;62:971-988.

86 Abed M, Towhid ST, Mia S, Pakladok T, Alesutan I, Borst O, Gawaz M, Gulbins E, Lang F: Sphingomyelinaseinduced adhesion of eryptotic erythrocytes to endothelial cells. Am J Physiol Cell Physiol 2012;303:C991999.

87 Closse C, Dachary-Prigent J, Boisseau MR: Phosphatidylserine-related adhesion of human erythrocytes to vascular endothelium. Br J Haematol 1999;107:300-302.

88 Gallagher PG, Chang SH, Rettig MP, Neely JE, Hillery CA, Smith BD, Low PS: Altered erythrocyte endothelial adherence and membrane phospholipid asymmetry in hereditary hydrocytosis. Blood 2003;101:46254627.

89 Pandolfi A, Di Pietro N, Sirolli V, Giardinelli A, Di Silvestre S, Amoroso L, Di Tomo P, Capani F, Consoli A, Bonomini M: Mechanisms of uremic erythrocyte-induced adhesion of human monocytes to cultured endothelial cells. J Cell Physiol 2007;213:699-709.

90 Wood BL, Gibson DF, Tait JF: Increased erythrocyte phosphatidylserine exposure in sickle cell disease: flowcytometric measurement and clinical associations. Blood 1996;88:1873-1880. 